\title{
Mind the Gap: The Big House in Cinematic Representations of the Anglo-Irish War
}

\author{
Shannon Wells-Lassagne
}

\section{(2) OpenEdition \\ 1 Journals}

\section{Electronic version}

URL: http://journals.openedition.org/etudesirlandaises/5686

DOI: 10.4000/etudesirlandaises.5686

ISSN: 2259-8863

\section{Publisher}

Presses universitaires de Caen

\section{Printed version}

Date of publication: 18 December 2018

Number of pages: $79-90$

ISBN: 978-2-7535-7693-3

ISSN: 0183-973X

\section{Electronic reference}

Shannon Wells-Lassagne, « Mind the Gap: The Big House in Cinematic Representations of the AngloIrish War », Études irlandaises [Online], 43-2 | 2018, Online since 01 November 2018, connection on 14 September 2019. URL : http://journals.openedition.org/etudesirlandaises/5686 ; DOI : 10.4000/ etudesirlandaises.5686 


\title{
Mind the Gap: The Big House in Cinematic Representations of the Anglo-Irish War
}

\author{
Shannon WeLls-Lassagne \\ Université de Bourgogne
}

\begin{abstract}
It goes without saying that the Big House was intended to be a symbol: as more than one critic has remarked, these houses really were only "big" in comparison to the poverty of the lesser structures that surrounded them. They were to be a bastion for British and Anglo-Irish culture and a center for social and administrative interactions. In this sense, they straddled the gap between the towns of Dublin and London, whence their power came, and the villages to whom they administered: it is no coincidence that these garrisons of British power bore the brunt of Republican anger during the Troubles of 1919-1921. Examining two of the rare films to focus on the War of Independence from the perspective of rural Ireland (The Wind that Shakes the Barley, Ken Loach 2006, The Last September, Deborah Warner 1999) allows us to examine the representation of the Big House and its place between the Irish village and the British-ruled town. Loach's film, which emphasizes the Socialist associations of the Anglo-Irish War and is unflinching in its portrayal of the brutality of British rule, highlights Republicans blending in to the landscape, walking from the activity of the village to the windswept hills of the countryside; the Big House, however, is reached only by (Black-and-Tan) jeep, and though landowner Sir John Hamilton may know his own servants, he fails to recognize the Republican members of the community. Deborah Warner's The Last September takes a more clearly revisionist stance, and can be seen adding both the Irish and the British to its adaptation of Elizabeth Bowen's novel about an Anglo-Irish family residing in the Big House of Danielstown during the war. In so doing, the Naylors become the middlemen in the struggle between the Black-and-Tans and the Republicans, once again associated respectively with town and country. In so doing, the films "mind the gap", focusing on the Big House, so obviously present in the landscape, but which ultimately symbolizes the absence of middle ground between the two factions.
\end{abstract}

Keywords: Wind that Shakes the Barley, The Last September (film), Anglo-Irish War, Troubles, Big House, heritage film, War of Independence.

\section{Résumé}

La Big House irlandaise avait bien évidemment une valeur hautement symbolique : comme plusieurs critiques l'ont signalé, ces maisons neétaient vraiment "grandes" que par rapport à la pauvreté des structures qui les entouraient. Ils étaient conçus comme un siège culturel britannique et angloirlandais, le lieu d'échanges sociaux et administratifs. Dans ce sens, ils rapprochent les grandes villes comme Dublin et Londres, d'où vient ce pouvoir, des villages auxquels ils administrent: ce n'est pas un hasard que ces remparts du pouvoir britannique ont été un cible de choix de la colère républicaine pendant les Troubles de 1919-1921. Analyser deux des rares films à traiter de la Guerre 
d'Indépendance du point de vue de l'Irlande rurale (The Wind that Shakes the Barley, Ken Loach 2006, The Last September, Deborah Warner 1999) permet d'examiner la représentation de la Big House et de sa place entre le village irlandais et la ville sous emprise britannique. Le film de Loach, qui accentue les implications socialistes de la guerre anglo-irlandaise et présente la brutalité de la règne britannique sans broncher, souligne la capacité des républicains de se fondre dans le paysage, passant de l'activité du village aux collines de la campagne ; la Big House, toutefois, est accessible uniquement par jeep (rempli de Black et Tans), et si le propriétaire Sir John Hamilton connaît ses propres domestiques, il ne sait reconnaître les membres républicains de la communauté. The Last September de Deborah Warner se situe dans une veine plus explicitement révisionniste, et rajoute des personnages irlandais et britanniques à la trame de l'adaptation du roman d'Elizabeth Bowen qui traite d'une famille anglo-irlandaise qui habite la Big House Danielstown pendant la guerre. Ce faisant, les Naylor se retrouvent tiraillés entre les Black et Tans et les républicains pendant ce conflit, les deux groupes étant associés de nouveau à la ville et à la campagne, respectivement. Ainsi, les films soulignent la faille entre les deux lieux en focalisant l'attention sur la Big House, qui domine le paysage irlandais, mais qui symbolise finalement l'absence de terrain d'entente entre les deux factions.

Mots clés: Wind that Shakes the Barley, The Last September (film), guerre anglo-irlandaise, Troubles, Big House, guerre d'Indépendance.

As my title indicates, this article will be focusing on "the gap" - between Ireland, Anglo-Ireland and Britain, as well as the gaps implicit in these and indeed any representations of the War of Independence. These gaps, I suggest, are manifested in the very nature of the Big House. As both a concrete object and a symbol, the Big House is fraught with meanings. It is of course the focal point for Ascendancy power, a manifestation of Anglo-Irish occupation of the country, but also, as Elizabeth Bowen insists, a promise of civility. As the owner of a Big House herself, she argued that these structures were in fact the incarnation of Anglo-Irish hopes of civility, and as such were perhaps even more necessary after the trauma of the War of Independence and the Civil War than they were before it.

There was a true bigness, a sort of impersonality, in the manner in which these houses were conceived. After an era of greed, roughness, and panic, after an era of camping in charred or desolate ruins (as my Cromwellian ancestors did certainly) these new settlers who had been imposed on Ireland began to wish to add something to life. The security that they had, by the eighteenth century, however ignobly gained, they did not use quite ignobly. They began to feel, and exert, the European idea - to seek what was humanistic, classic and disciplined. [...] From the point of view of the outside Irish world, does the big house justify its existence? I believe it could do so now as never before. As I said, the idea from which these houses sprung was, before everything, a social one; [...] 'Can we not,' big, half-empty rooms seem to ask, 'be as never before, sociable? 
Cannot we scrap the past, with its bitterness and barriers, and all meet, throwing in what we have?'

In this essay, entitled "The Big House," Bowen posits a central diplomatic role for the titular structure ${ }^{2}$. As the author remarked in this essay and elsewhere, these houses really were only "big" in comparison to the poverty of the lesser structures that surrounded them ${ }^{3}$; Though they were to be a bastion for British and Anglo-Irish culture and a center for social and administrative interactions, ultimately they were a stronger metaphorical and political presence than they were impressive architectural landmarks. In this sense, they straddled the gap between the towns of Dublin and London, whence their power came, and the villages to whom they administered: it is no coincidence that these garrisons of British power bore the brunt of Republican anger during the Troubles of 1919-1921. In this sense, given the inherent tendency towards symbol and allegory in historical film, itself characterized by their "gaps," since the narrative impulse that dominates Western cinema requires historical films to distort, allegorize, and condense historical events into a unified plot, the Big House becomes a key image in the representation of the Irish War of Independence. Examining two of the rare films to focus on this conflict from the perspective of rural Ireland (The Wind that Shakes the Barley, Ken Loach 2006, The Last September, Deborah Warner 1999) allows us to examine the representation of the Big House and its place between the Irish village and the British-ruled town, present in absentia in the films. I suggest that though these structures were meant to breach the gap between town and country, between British power and Irish tenantry, both films ultimately emphasize the chasm that separates the two, and as such the films center on the idea of absence, of loss: to the extent that this gap is to be bridged, this will not take place in the Big House, but outside it.

Given the importance of figures of absence or marginality in these two films, it seems crucial to understand the context in the margins of the two narratives (both in terms of production and plot) so as to fully appreciate their representation of the Big House. The lesser known of the two films, The Last September, is an adap-

1. Elizabeth Bowen, The Mulberry Tree, p. 27, p. 29.

2. Perhaps one of the more obvious gaps in this article is the presence of Bowen herself; as author of the source text for The Last September, as author of this essay that inspired the following analysis of The Last September and The Wind that Shakes the Barley, Elizabeth Bowen is also a central (absent) figure here.

3. Bowen herself commented that her family home, Bowen's Court, was "larger in manner than in actual size", and further commented in an essay entitled "The Big House": "The paradox of these big houses is that often they are not big at all. [...] Is it height - in this country of otherwise low buildings - that got these Anglo-Irish houses their 'big' name? Or have they been called 'big' with a slight inflection - that of hostility, irony? One may call a man 'big' with just that inflection because he seems to think the hell of himself." Elizabeth Bowen, Bowen's Court (1942), Cork, Collins Press, 1998, p. 31; Elizabeth Bowen, “The Big House”, In Hermione Lee, ed. The Mulberry Tree: Collected Writings of Elizabeth Bowen, San Diego: Harcourt Brace Jovanovich, 1986, p. 26. 
tation of Elizabeth Bowen's novel, written by Irish novelist John Banville in his first screenplay, and directed by Deborah Warner in her first film. Banville is of course famous for exploding the genre of the Big House novel in texts like Birchwood, and Warner was well-known in the theater world, notably for her longtime association with Fiona Shaw and her tendency to cast her in gender-bending roles (like the titular role in Shakespeare's Richard II). The film deals with the mounting opposition to the British occupation of the country as seen from the perspective of the local Anglo-Irish family, the Naylors, who live in Danielstown with their niece and nephew, Lois and Laurence, and three family friends who are visiting, the Montmorencys (Hugo and Francie) and Marda Norton. Lois is the protagonist of the film, a young woman described by Marda as being "desperate to fall in love", and is being courted by ineffectual soldier Gerald Colthurst, though she is enamoured of her childhood friend Peter Connelly, the brother of her best friend Livvy, who has joined Republican forces in fighting against the British. The lovers meet at an abandoned mill where they played as children; it also serves as a convenient hiding-place for Peter, on the run from British forces. The relationship between the young Anglo-Irish girl from the Big House and the Irish rebel is fraught with tension, and Peter's advances grow increasingly violent. The seduction/attempted rape is interrupted by the arrival of Gerald, who has come to investigate despite the fact that Lois has already broken off their relationship, and as a wounded Lois runs out (having insisted that Peter inflict an injury on her in order to save her honor) Gerald is shot by Connelly. The film ends with Lois fleeing Danielstown, joining Marda on her honeymoon.

Ken Loach's The Wind that Shakes the Barley, as the winner of 2006's Palme d'Or at the Cannes Film Festival, and the work of a much-lauded (and criticized) director, is the better known of the two films; it can easily be seen as a continuation of the filmmaker's previous outings: Hidden Agenda (1990) had already dealt with the difficult relation between the British and the Irish (in contemporary Northern Ireland), and Land and Freedom (1995) had broached the topic of a national revolution that failed to spawn the socialist republic so many were hoping for. The Wind that Shakes the Barley depicts the Irish war of independence through the relationship of two brothers, Teddy and Damien. Damien intends to go to London to pursue his career as a doctor, while Teddy has joined a Flying Column of the IRA and begs Damien to stay and fight. After witnessing the fatal beating of a young man for refusing to speak English rather than Gaelic, and the brutality of British soldiers who refuse to acknowledge the train union's decision to not carry British troops or munitions, Damien decides to stay, and begins his military training. An initial raid of the barracks for arms is followed by the shooting of officers, and the British investigate by paying a visit to the local Big House, the Reed estate, where the Anglo-Irish landowner, Sir John Hamilton, 
forces one of the laborers involved, Chris Riley, to confess. The rebels are captured and tortured, only to be saved by a British soldier with Irish heritage of his own, and they in turn find themselves at the Big House, where they kidnap Chris and Sir John. After a forced march into the Irish countryside, the two British conspirators are then put to death. The cycle of violence is suddenly interrupted by news of the Anglo-Irish Treaty, and after celebrating the truce, the Treaty further divides the group, caught between the idealist desire for complete separation from Britain and a socialist nation, and the pragmatic resignation in accepting what's offered. Damien and Teddy find themselves on opposite sides of the argument, and when Teddy dons the uniform of a Free State officer and Damien continues in the IRA, the younger sibling is soon captured, interrogated on the whereabouts of ammunition, and shot by a firing squad - on the orders of his sibling, who shoots him himself.

Of course, in describing the two films, the gap between the two also becomes apparent: The Last September is very much a heritage film, whose historical backdrop is sometimes relegated to a setting for a coming-of-age romance, complete with lingering shots of period paintings and saturated colors, focusing on the elegance of the Ascendancy lifestyle (albeit while critiquing that extravagance) in a manner reminiscent Andrew Higson's description of the genre ${ }^{4}$; The Wind the Shakes the Barley, however, like all Loach films, places itself firmly in the realm of social realism, where laborers have pride of place, and as much time is allotted to Dáil court cases as to the consummation of the romantic subplot ${ }^{5}$. However, both films have significant similarities that justify setting them in relation to one another. As mentioned above, they are rare examples of the Independence movement seen from a rural perspective, without famous figures like Michael Collins to anchor the narrative (Neil Jordan, 1996); both insist on the impact of political intrigue on those initially isolated from it, the slow recognition of the inevitability of change. Though their approaches are very different, ultimately their conclusions are similar, providing a mirrored perspective of the conflict (from an AngloIrish standpoint in The Last September, and from a rebel's standpoint in The Wind that Shakes the Barley).

4. " $[\mathrm{H}]$ istorical narrative is transformed into spectacle; heritage becomes excess, not functional mise-en-scène, not something to be used narratively, but something to be admired. [...] This heritage presence is enhanced by the visual style that the film-makers have adopted, what I've called the aesthetics of display-that is, a particular use of the camera and a particular way of editing that works superbly to display as spectacle this range of heritage properties." Andrew HigsonHigson, Andrew, English Heritage, English Cinema: Costume Drama since 1980, Oxford: Oxford University Press, 2003, 39 and 172.

5. Even the romance is given political significance, as when the protagonist undresses his lover, a cliché of the love scene, here he unwraps the turban hiding her bald head, shorn by Black and Tans in retribution for rebel actions. 
In Declan Kiberd's landmark work Inventing Ireland, his discussion of the Big House novels as practiced by Somerville and Ross insists on contextualizing with a description of the difficult affinities of the Anglo-Irish:

England, by the final decades of the nineteenth century, was a very changed place, heavily industrialized and filled with a new élite, whose social standing derived more from money than from land. Many leaders of English society were now openly hostile to aristocrats: and even those who admired people of caste were by no means certain that the occupants of draughty, decaying mansions in windswept Irish landscapes really counted as 'top drawer'. Ever since the time of Jonathan Swift, there had been pressure on the Anglo-Irish to throw in their lot with the natives. $[\ldots]$ it became more and more clear that a strange reciprocity bound members of the ascendancy to those peasants with whom they shared the Irish predicament. [...] It was the new economic pressure [of the Land Acts] which compelled both Somerville and Martin to turn to art for a living which the big house could no longer provide but also for a fully comprehensive image of the crisis. Their profound Christian convictions led them to a tragic sense of the underlying injustice of their own privileged position, while their concern for family tradition led them to lament what seemed sadly like the end of the line. ${ }^{6}$

Both Kiberd and Otto Rauchbauer, who edited Ancestral Voices: The Big House in Anglo-Irish Literature, suggest that the exchange between the two populations is central to the Big House novel; Rauchbauer for example, among his five characteristics of the Anglo-Irish novel, cites "a critique of absenteeism as well as outright recommendation of paternalistic estate management", suggesting that the crux of the Big House tradition is the successful interaction between the landowner and his tenants.

In this case, then, the Big House is ideally the meeting-ground between British and Anglo-Irish power and Irish rebellion (making their widespread destruction during the Anglo-Irish War all the more significant as a symbol of the destruction of any middle-ground). At the same time, the structure represents the gap itself, as it is the material incarnation of the distinction made between the generally Protestant gentry and the generally Catholic tenantry.

However, it seems that discussion of the Big House has in a sense always been retrospective, after the decline of the society it housed: the Somerville and Ross novels testify to the end of an era, and Bowen speaks of Big Houses under

6. Declan Kiberd, Inventing Ireland: The Literature of the Modern Nation, London: Vintage, 1996, 67-68.

7. "The Big House and Irish History: An Introductory Sketch", in Otto Rauchbauer, ed., Ancestral Voices: The Big House in Anglo-Irish Literature, Hildesheim: Georg Olms Verlag, 1992, p. 19. 
new owners, in the aftermath of the strife caused by independence and civil war. Likewise, in these films depicting the guerrilla war fought by the IRA for independence, the possibility of consensus, of a meeting point, is already gone.

The principal testament to the lost role of the Big House as meeting place is to be found in its geographical and cultural isolation, where it becomes the physical manifestation of the gap itself between village and town. As Ruth remarks in Irish National Cinema, the Big House is "the concrete embodiment of colonial rule in Ireland [...] The stately homes of the English films and the society that inhabits them are structured on a naturalised hierarchical system [...] In [...] Irish films, [unlike their British counterparts,] the Big House is both alien to the landscape and under constant threat, of decay and attack."

Thus in The Wind that Shakes the Barley, the removal of the Reed estate from the village occupied by the British is emphasized: the troops must take jeeps to arrive there, and it is only seen twice, once to show landowner Sir John forcing one of his workers to inform on his fellow IRA members, and once for said rebels to find him and take him hostage in hopes of keeping their comrades alive. When the two factions meet, their conversation insists on both the physical distance that separates the Big House from the village (and its prison where the rebels have been held), as well as the emotional distance that the landowner's lack of empathy makes unbreachable:

'This is a lovely room; it's hard to imagine a man's scream from here. Have you seen fingernails ripped out with a rusty pair of pliers, Sir John? All your learning, and you still don't understand.' 'Oh, I understand perfectly, Mr. O’Donovan. God preserve Ireland if ever your kind take control.' (46:48)

Clearly, in Loach's rendition of the war, the Big House is geographically, politically, and emotionally peripheral to the primary conflict, and the possible interactions between town and country implicit in the Big House are thwarted by architecture - the Anglo-Irish are in the drawing-room, while the Irish laborers are limited to working in the stables, not indoors (24:07-26:06). In The Last September, the Big House is the primary setting of the film, and as such is of course central - however, though almost all characters gravitate around Danielstown, ultimately the action scenes, the scenes of actual conflict, take place elsewhere, and the repeated establishing shots show a Big House that is utterly isolated, almost overwhelmed by the surrounding countryside (where dandelions are symbolically running to seed, suggesting that the Big House they frame may also be past its prime). The physical divide between the different factions is ironically

8. Ruth Barton, Irish National Cinema, London: Routledge, 2004, 121. 
even more absolute in The Last September than in Loach's film: neither Irish and British characters actually penetrate the depths of the house; they ultimately remain on the threshold and do not go beyond the entry of the house proper, whether it be for a tennis party or to deliver the mail and tell the latest news. As such, the representations of the town and the country, i.e. British power and Irish rebels, become radicalized in both films. Thus, in The Wind that Shakes the Barley, the British army is associated with industrialization, making use of jeeps, motorcycles, and lorries, and dressed in uniforms, the Irish are unabashedly associated with the countryside, shown either attempting to blend in with the countryside in their training, or actually succeeding as they march through the fog to make a successful raid (1:04:12-1:05:25), and are never shown in any kind of motorized vehicle - they walk, they take a horse and trap, they use bicycles, but are clearly made to seem at odds with this industrialization (the viewer can notice the motorcycle one of the rebels obtains is not being ridden, and is in fact part of the disguise used to attack the Black and Tans, feigning the guise of a soldier with a broken-down vehicle) $)^{9}$. Rebels in The Last September are similarly associated with the countryside (as in our first glimpse of the rebels through the tree line, 4:55), which makes the encroaching nature in the establishing shots suddenly invasive, hostile: it's as if the country itself is rising up against them, as actress Fiona Shaw remarked ${ }^{10}$. The film shows that the Anglo-Irish are associated only with refracted or contained versions of nature, as we see at the end of the long opening credit sequence, featuring cut flowers in vases (with falling petals) and a preserved flower in a glass sphere (6:19-6:34), as well as in the extensive use of lush and exotic vegetation in scenes of the conservatory (20:36-53), where the camera shot showing the conservatory and the dinner party being held there from outside the glass walls becomes an apt translation of Bowen's original passage where the meal is not in the conservatory, but where the inhabitants find themselves "enisled"11.

Ultimately, then, this radicalization of the two factions, industrialization and rural living, English and Irish, are depicted through symbolic passages representing the chasm that exists between the opposing forces. In The Last September, which centers on the position of the Anglo-Irish, and "the death of a world", as the opening titles tell us, the tree swing that our protagonist Lois returns to again and again epitomizes the position of the film's Anglo-Irish contingency, moving back and forth between allegiance to the British or the Irish without being able to choose between the two (23:40, 1:37:24-1:38, 1:39:06-1:39:42). The last sequence mentioned here is particularly interesting, as the subjective camera shifts its perspective;

\footnotetext{
9. This of course relates to Loach's larger premise associating the rebels with a pre-industrial, and arguably precapitalist society.

10. Interview with Fiona Shaw, Bonus, DVD The Last September.

11. Elizabeth Bowen, The Last September (1929), London: Penguin, 1987, p. 24.
} 
while the subjective camera is initially motivated by Lois's actions, we go on to take the swing's perspective - we the audience have taken her place, and its metaphorical meaning has become literal - perspective has clearly been lost.

In The Wind that Shakes the Barley, the metaphor for the unbreachable divide between town and country, English and Irish, is linguistic. When Black and Tans harass the principal characters for assembling (and participating in a hurling match), they demand names, occupations, and addresses, and the response of one young man in Gaelic is enough to have dire consequences (4:52-8:00). The double identity of the boy, as Micheál/Michael Sullivan becomes indicative of the split of the Irish psyche. Since the film makes fairly extensive use of Gaelic that is pointedly not translated in the English or foreign subtitles, the gap in understanding between the two people is shared by an Anglophone audience, emphasizing the already the distinction already present in the back and forth between various British and Irish accents.

Ultimately there is a feeling of absence in both films, exacerbated by the inevitability of each narrative's tragic outcomes. The function that the Big House was intended to fill, as a relay of influence and information between English and Irish, as a place of exchange between the two, as the intermediary between town and country, has been left empty (and in The Last September at least, we are left swaying with the wind...). So for example The Wind that Shakes the Barley is permeated with the absence of James Connolly, the Socialist Republican shot in the wake of the Easter Rising that arguably put an end to a left-wing solution to the stirrings of revolution. Protagonist Damien and his mentor Dan are both inspired by Connolly's speeches, and parrot his words when arguing against the Anglo-Irish Treaty, insisting that to not push for a socialist country is essentially to simply change the accent of their oppressors. Loach goes so far as to have the characters first recite the speech together, and later use it in a debate about unfair lending practices from a merchant who supports IRA troops. In a sense, the tragic tone of the film is not so much linked to the war itself as of the path not followed, the leader who might have clarified the distinctions to be made for or against the Treaty in a way that De Valera did not. The idea of the Anglo-Irish providing some sort of middle-ground is here explicitly refused, both in the limited time given to both Sir John and his demesne, and in the landowner's unabashed and unequivocal identification with the British, crying out "You'll never beat us" upon being killed, and treating both rebels and country with disdain ("rustics with delusions of grandeur" and "a priest-infested backwater", respectively). In this, the Anglo-Irish simply become English squatters, without any pretensions at Irish nationality.

In The Last September, the spectre is again twofold. Elizabeth Bowen's novel seems a fundamental presence in the film. The written text is much more critical 
of the Anglo-Irish than is the film, as the Irish are voluntarily absent (a fact that Sean O'Faolain famously deplored ${ }^{12}$ ) while the Danielstown inhabitants attempt valiantly to ignore their plight; their home is eventually destroyed, it is implied, as much by their blindness as by the actions of rebels. The text is also much more radical in its refusal of all traditions, literary or political, as the heroine spends her time deploring the fact that she's unable to live like a heroine in a historical novel, unable to love her young soldier or feel much of anything about her situation except resignation, and even the novel's elegiac tone is curtailed by the many examples of humor and grotesque. Ironically, though Banville and Warner take pains to include the conflict in their story in a much more obvious way than did Bowen, one can say that the scope of the conflict itself is also missing, as the nameless rebels that populate the book, that seem part of the countryside rising up against the Anglo-Irish, are in the film reduced to a single member, Peter Connolly, né Connor in Bowen's novel, whose ultimate purpose is to make Lois's allegiances clear (does she love the rebel or the soldier?).

The encounter that the Big House might have offered is to be found elsewhere, ultimately: the hospitality Bowen hopes the Big House will offer in an attempt at putting enmity behind them is recurrent amongst the Irish families in The Wind that Shakes the Barley, where the rebels are assured of food and shelter wherever they stop along the way, the solidarity of a nascent and innate socialism as the director's ideal, while the British are unable to share even a billiard table, and Sir John has hospitality only for the British officers. Ultimately, the function sought out for the Big House is occupied in the film by Peggy's house, a home that has seen generations of difficulties, where families and friends repeatedly meet, the scene for the repeated conflict between the Black and Tans and the Flying Column members. Indeed, the house suffers the same fate as many of the Big Houses of the time, being set afire like Bowen's version of Danielstown. In Laverty and Loach's vision of the conflict, the Anglo-Irish are to be excluded altogether from this conflict.

In The Last September as well, encounters happen not at the Big House, but in the abandoned mill, where Lois can meet with her childhood love (Peter Connelly) and Gerald can learn the truth of the futility of British intervention in Ireland: clearly, we're shown, the Irish (Anglo-Irish or Irish) must solve this among themselves. However, like Peggy's house in The Wind that Shakes the Barley, the place is ultimately marred by violence (Connelly's aggressive behavior towards Lois, and then his assassination of Gerald), and both films end with exile. Teddy is ordered away from the house when Sínead learns that he's had his brother exe-

12. He suggested that it showed the Ascendancy unaware "of the Ireland outside its walls". Hermione Lee, Elizabeth Bowen (1981), London: Vintage, 1999, 45. 
cuted, an exile that was previously implicit in Peggy's daughter Brigitte's indignation that the Free State soldiers would search her home for arms like the British had done, even after they had given them food and shelter. Lois is shown leaving with Marda while a family portrait peers out from the window, suggesting she is fleeing not just the conflict, but the weight of family expectations both personal and social.

If the narratives end without a sense of resolution, departing the place where all can meet, one can wonder if the films themselves are an attempt to breach this gap, not only between town and country, the Irish, the Anglo-Irish, and the British, but also between the past and the present? Films are of course by their expensive and collaborative nature meant to be accessible to the general public, bringing a difficult period in both British and Irish history to light for town and country. But the final similarity between these two films is perhaps this larger political significance (for their filmmakers and for their audiences). Both directors have commented on the relevance of the films as allegories for current events. Warner speaks of the plight of the Anglo-Irish as being evocative of American hegemony:

It's also a very sobering reminder to us all that things change, that we may feel very sure of where we are $[. .$.$] America feels very sure of where$ it is, England feels pretty sure of where it is, so too the Anglo-Irish felt very sure of where they were. And yet, by the end of that year of which this last September is a part, they were to be eclipsed and never seen again, because Ireland needed to move towards its democracy, towards its future, and I think it becomes a very meaningful and very very contemporary tale in that respect. ${ }^{13}$

Actress Fiona Shaw (who plays Marda) goes even further, suggesting that "The Last September is more pertinent now than it was when it was written ${ }^{14 "}$, associating Anglo-Irish identity problems with conflict in the Balkans, where "people who seem to be getting along, who seem to be of the same race to anybody from the outside, in fact are full of histories that divide them". For Ken Loach, The Wind that Shakes the Barley could be taken as a commentary on the futility of occupying armies in any country - though the occupation of Iraq at the time of its release was often pointed to as a pertinent example ${ }^{15}$. Indeed, Loach's comment upon receiving the Palme d'Or at Cannes for The Wind that Shakes the Barley was

13. Interview with Deborah Warner, Bonus, DVD The Last September.

14. Interview with Fiona Shaw, op. cit.

15. Loach comments: "It [The film] has a resonance to any armed occupation and to any anti-colonial struggle [...] But Iraq wasn't an influence. Paul wrote the screenplay before we were in Iraq. We've been discussing this story for 10 years." David Gritten, "Hate Britain? Of course I Don't," The Telegraph, June 16, 2006. [http://www. telegraph.co.uk/culture/film/3653150/Hate-Britain-Of-course-I-dont.html]. Accessed 11 July 2017. 
that in understanding the past maybe we can understand the present. Nostalgia, fascination for the past so often seen in historical films, fetish for period authenticity, here meant to instruct instead of simply to please aesthetically. In this sense, the framing mechanism of the doorway that permeates The Last September takes on a new meaning: beyond showing the limitations of the different characters, who never cross over, we can say that film can, and does, breach those thresholds. 